$A D D I N$, Volume 12, Number 2, Agustus 2018

\title{
THE ISLAMIC MASS ORGANIZATION CONTRIBUTION IN PROTECTING THE RELIGIOSITY INCLUSIVE AND DIVERSITY IN INDONESIA
}

\section{Masrukhin}

masrukhinkhin@gmail.com

\section{Supaat}

supaatkudus@yahoo.com

\section{Abstract}

This study aims to describe the contribution of Islamic community organizations (ormas) in maintaining diversity and religiousness are inclusive in Indonesia. This research uses qualitative approach and kind of research of Secondary Data Analysis (SDA). Data collection techniques with secondary data through the internet media. Data analysis techniques using three steps are: (1). Indentifying sources of information, (2). Gathering existing data, (3). Normalizing data of needed, (4). Analyzing data.The results of this study found: (1) The existence of Islamic organizations in Indonesia can be seen from three things: (a). Indonesia is a country that has diversity in the life of the community, the existence of Islamic organizations if managed properly communicative, controlled, transparent and accountable, it will be able to become a buffer in national development, (b) Popularity of Islamic organizations in the perspective of students there are five: Nabdlatul Ulama, Mubmmadiyah, Front Pembela Islam (FPI), 
Lembaga Dakwah Islam Indonesia and Hizbut Tabrir Indonesia. Organizations of Islamic societies that are considered popular by students are NU and Mubammadiyah, (c) The Government is obliged to discipline all existing organizations by making a set of rules in the form of Ormas Ordinances and Government Regulations. Real mass organizations are against the value of Pancasila and the UUD 1945, the government is entitled to be given warning, guidance until the revocation of the permit of the relevant organization, (2). Indonesia is a plural country. Pluralism can be seen from the diversity and religiousness of the community. The pluralism of the Indonesian people encourages us to unite in the unitary state of the unity of the Indonesian republic, (3). The formation of Islamic organizations aims to maintain unity and unity of the nation and also as a media aspirations of the community. The role of Islamic Organizations in maintaining diversity and religiousness that are inclusive in Indonesia can be seen two forms of Islamic mass organizations proven in history plays an important role in maintaining pluralism in Indonesia and Islamic organizations contribute positively to the development of Islamic education in Indonesia, (4). Islamic organizations in historical development have experienced many obstacles both internally and externally, government support is very important in the development of Islamic organizations in Indonesia.

Keywords: Contribution, Organization of Islamic Society, Diversity, and Inclusive Religious.

\section{Abstrak}

Penelitian ini bertujuan mendeskripsikan tentang kontribusi organisasi masyarakat (ormas) Islam dalam menjaga keragaman dan keberagamaan yang inklusif di Indonesia.Penelitian ini menggunakan pendekatan kualitatif dan jenis penelitian Analisis Data Sekunder (ADS). Teknik pengumpulan data dengan berbasis data sekunder (secondary data) melalui media internet. Teknik analisis data dengan menggunakan tiga langkah yaitu: (1). Indentifying sources of information, (2). Gathering existing data), (3). Normalizing data of 
needed, (4). Analyzing data. Hasilpenelitian ini menemukan tentang: (1) Keberadaan organisasi kemasyarakatan (ormas) Islam di Indonesia dapat dilihat dari tiga hal yaitu: (a).Indonesia merupakan negara yang memiliki keragaman dalam kehidupan masyarakat, keberadaan ormas Islam apabila dikelola dengan baik secara komunikatif, terkontrol, transparan, dan akuntabel, justru akan mampu menjadi penyangga dalam pembangunan nasional, (b) Popularitas ormas Islam dalam perspektif mahasiswa dan pelajar ada lima yaitu: Nahdlatul Ulama, Mubmmadiyah, Front Pembela Islam (FPI), Lembaga Dakwah Islam Indonesia, dan Hizbut Tabrir Indonesia. Organisasi masyarakat Islam yang dianggap populer oleh pelajar yaitu NU dan Mubammadiyah, (c) Pemerintah berkewajiban untuk menertibkan semua ormas yang ada dengan membuat seperangkat peraturan berupa Undang-Undang Ormas dan Peraturan Pemerintah. Ormas yang nyata bertentangan dengan nilai Pancasila dan UUD 1945, pemerintah berhak untuk diberikan peringatan, pembinaan sampai pada pencabutan ijin ormas bersangkutan, (2). Indonesia merupakan negara yang majemuk. Kemajemukan tersebut dapat dilihat dari keragaman dan keberagamaan masyarakat. Kebhenikaan masyarakat Indonesia tersebut mendorong kita untuk bersatu dalam wadah negara kesatuan republik Indonesia, (3). Terbentuknya ormas Islam bertujuan untuk menjaga persatuan dan kesatuan bangsa dan juga sebagai media aspirasi masyarakat. Peran Ormas Islam dalam menjaga keragaman dan keberagamaan yang inklusif di Indonesia dapat terlihat dua bentuk yaitu ormas Islam terbukti dalam sejarah berperan penting dalam menjaga kebhenikaan di Indonesia dan ormas Islam berkontribusi positif dalam perkembangan pendidikan Islam di Indonesia, (4). Ormas Islam dalam perkembangan sejarah telah mengalami banyak hambatan baik secara internal maupun eksternal, dukungan pemerintah sangat penting dalam perkembangan ormas Islam di Indonesia.

Kata Kunci: Kontribusi, Organisasi Masyarakat Islam, Keragaman, dan Keberagmaan yang Inklusif 


\section{A. Background}

Indonesia as the island nation has a vast territory, stretching from Aceh to Papua. There are 17,504 islands and it consist of 8,651 island which has name and 8,853 nameless island spread all over the Indonesian territory (Situmorang, 2006 dalam Ruskhan Gaffar Abdul, 2007, p. 2). In addition, Indonesia is a multiple communities with differencies character countries. This can be seen from the diversity of the communities (plural society) which consists of two or more social order that coexist. Indonesia is the country that not only has the diversity but it has multiethnicalso (like Madura, Lombok, Dayak, Papua, Kutai, Makasar, Bugis, Jawa, Sunda, Batak, Aceh, Flores, Bali, and so forth). There also multimental dan ideological interest (Indian, Chinese,Netherlands, Portugal, Hinduism, Buddhism's, Confucianism, Islam, Christianity, capitalism, and so forth). There are more than 250 ethnic groups, with the majority of the population is Javanese. According to PODES in year of 2014 there are 71,8 percent Indonesian villages has multi-etnic society.This shows villages' ethnic diversity in Indonesia. The language uses are the vernacular. The data from SUSENAS MSBP 2015 there are 58,95 Indonesian uses vernacular language in their milieu or even in the office.A very rarely used language is a foreign language, which is only used by 0.09 percent of the population. Generally both at home and in the association, the majority of the population uses local languages (Dokhi Muhammad, 2016, p. ii).

Indonesia is a country that has religious character.This can be seen from the diversity of community based religion. According to the Ministry of Home Affairs the number of community organizations on 2017 around 344,039. There are 370 organizations do not have legal evidence(Kementerian Dalam Negeri, 2017). Among them there are 72 Islamic 
organizations. In the religion diversity there are five biggest religion in Indonesia, Islam, Protestant, Catholic, Hindu and Buddhistplus the Confucianism and the Aliran Kepercayaan. Every religion contigious and keep the tolerance.Every religion is guaranteed free actualize their beliefs in everyday life. It is based on legal guarantee of article 29 paragraph 1 and 2 of 1945 Constitution that "Negara berdasarkan Ketuhanan Yang Maha Esa" dan "Negara menjamin kemerdekaan tiap-tiap penduduk untuk memeluk agamanya masing-masing dan untuk beribadat menurut agama dan kepercayaannya itu'(BPN, 2002, p. 9).

Such diversity is a reality that we have to realize and are thankful for. Where Indonesia is a Bhinneka Tunggal Ika nation. The ke-bbinekaanof Indonesiathe profitable assets is at once a threat. Diversity becomes something to note and look out for. This is because with this diversity, we could bring the productivity, but on the other hand if not managed properly thus sparking discordance(Rosita Endang Kusmaryani, 2011, p. 1). The reality of recent years shows that nearly all crimes committed in private, group, or organization often on behalf the religion. Then each group claimed that they are the truest group, most civilized, most ideal, the most appropriate, so that everything else must be straightened out. The phenomenon has been dragging the adherents of exclusive religious-minded (Firdaus M. Yunus, 2011, p. 220). Therefore the attitude of tolerance and respect is an attitude that needs to be developed by the community and community leaders. Attitude and behavior of this tolerance needs to be embodied to our generation since childhood. The embodiment tolerance process can be carried out on three levels of environment (milieu) on the level of family,school or community environment.Family is an environment to introduce the children the importance of 
appreciating each other among family members. The school environment is a place of abolishing a range of prejudices that lets children interact in social places. The school should be able to free the discriminatory attitudes among students. The environmental community has a function in disseminating and developing the characters that already preconceived.The conflict sourced from the diversity which frequently happens, in schools, college and communities is a very apprehensive. Indonesia is the ideal place to live together with each other and keeping the tolerance.So in implementing the values of religion and the believed become a potential conflict arena in the community. This is particularly likely to happen because all of this diversity and religiosity get less attention and not well managed.

\section{Formulation Of The Problem}

1. How Islamic community organizations in Indonesia?

2. How diversity and religiosity communities in Indonesia?

3. What is the role of the Islamic organization in maintaining an inclusive religiosity and diversity in Indonesia?

4. What are the factors that support and hinder the Islamic organisation in maintaining the diversity and religiosity in Indonesia?

\section{The Theory}

\section{Community Diversity and religiosity}

\section{a. The Community Diversity Concept}

Pluralism is defined as a form of recognition of the existence of diversity, there are many other things outside of our group to be recognized.Diversity looks at the existence of some differences such as age, race, ethnicity, gender or 
sexual orientation(Capuzzi, D. \& Gross, 1997, p. 37).The diversity recognition not only in recognition of the culture. But pluralism also recognizes the existence of a diversity of race, religion, culture, ethnicity, social stratification, and social class.Pluralism is also a form of recognition of the diversity existence between members of the community or groups. The conflict arises because there are the domination of the strong to the weak, the dominance of the majority to the minority.Conflicts can happen anytime as a result of unhealthy social interaction. The existence of the mutual claim to the truth from the perspective of their respective group and not to the existence of good communication. Whereas Multiculturalism is a term used to describe one's views about the variety of life on Earth, or cultural policies that emphasize about acceptance of the reality of diversity, and a variety of cultural. Multicultural existing in public life is concerned, a system of values, culture, habits, their personal religious beliefs and political (Mudzhar, 2005, p. 174). Multiculturalism demands the society for a full of good life and tolerance between groups of society as well as within the community itself, so that mutual understanding between cultures and Nations. The tolerance can be realized due to a desire to find the potential of equations and narrow the cultural differences that exist for cooperation, it can be conducted within the framework of creating a safe and peaceful life in the world.

The public relations-based pluralism and multiculturalism can be described as follows:
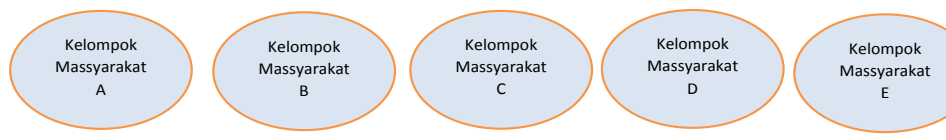

Figure 1. Community group-based interaction pattern Pluralism 


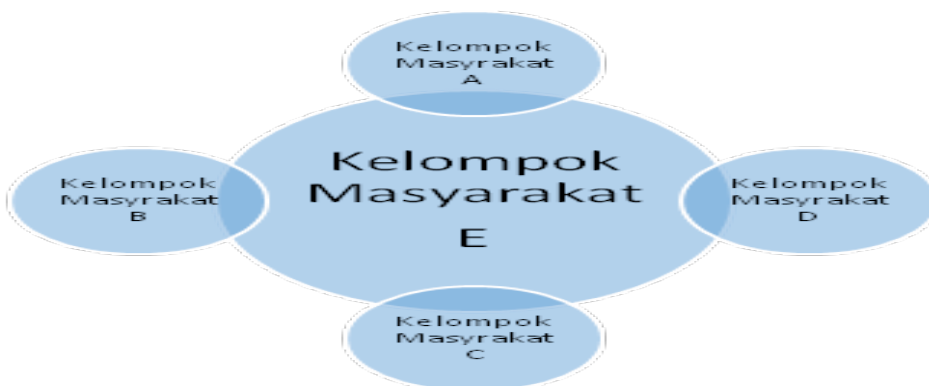

Figure 2. The Pluralism Community Group Interaction form

Diversity in the Islamic perspective can be seen inthe Quran in surahAl-Hujarat verse 13: "Hai manusia, sesunggubnya Kami menciptakan kamu dari seorang laki-laki dan seorang perempuan dan menjadikan kamu berbangsa-bangsa dan bersuku-suku supaya kamu saling kenal-mengenal. Sesunggubnya orang yang paling mulia diantara kamu disisi Allah ialah orang yang paling takwa diantara kamu. Sesunggubnya Allab Maha Mengetabui lagi Maha Mengenal" (QS. Al Hujarat; 49:13). This verses provides the Foundation to us in respond the community diversity. Allah Swt call us to recognize the character of men and women, the character of tribal, ethnic, character of society, communities and other nations of the world within the framework of mutual cooperation toward devotion to God Almighty to bring the safe world, peaceful, and prosperous. Indeed the most precious human in the alongside Allah Swtare their piety.

\section{b. Society Diversity}

Religion is one of the aspects listed in International Declaration of Human Rights. In this international declaration the world society must uphold the individuals' religiosity, communities, and Nations. Every individual has the freedom of thought, religion, and callous. A very human rights is grounded with awareness and self confidence and are not allowed to obtain the pressure from anyone $(\mathrm{Nuh}$, 2014, p. 2). The existing religiosity community that someone 
religiosity behavior in responding to the teachings that had been believed to be naturally experienced many distinction. It is visible by quantity (labiriyah) which it can be observable, empirical and measurable as well as the quality (batiniyah) filled with invisible meaning but largely determine the behaviour of a person in being and behaving. There are a few determining factors that cause different religious behavior.In the daily life every individual has the different religious experience.

The religiosity definition can be interpreted aspietyor religious commitment. The piety includes many elements such as religious beliefs, against the doctrine of life, ethics and presence in religious activities, as well as actions that indicate the behavior religiosity (Robertson Roland, 1993, p. 295). The religiosity behavior is determined by how large peoples' commitment or obedience in religion. Therefore religion is a great asset for national development. The national development who maximaze the peoples' religiosity potential automatically will get the peoples' support and participation. So that the national development will be run safely,orderly, and controlled to achieve national development goals.

The national development needs the safe, conducive and solicity situation in the context of ideology, politics, economy and social culture. Religion is supposed to be assets in national development and able to protect the whole system of social communities that exist. Religion is a social cohesion and it the important thing for the community. Religion produced the social system of religious societywhich based on non-empirical power.

The Religious functions can be divided into multiple dimensions: 1). Educational function, religion as a teacher, because the duty of religion is to teach and guide humans. 2).Social supervision function, religions responsibility to oversee the social norms in the society. The religion choose 
to establish good and bad rules.Religion give punishment to those who violate the standardized rules.3).Religion as a social stratification, the influence of religion in social life according to humans level of understanding the religion in society(Muhammad Ridho, 2016, pp. 9-10).

Rabmatan lil alamiin are the Islamic teaching for all of humans.Islam are the peace religion because love and peace is the priority.Islam always invites his people to cooperate with other people anywhere. Difference and pluralism is the Allah Swt inclination.As the word of Allah Swt:

"Iikalau Tuhanmu menghendaki, tentu Dia menjadikan manusia umat yang satu, tetapi mereka senantiasa berselisih pendapat”. (QS.Hud; 11: 18).

The meaning of the verse is to realize that humans carries diversity potential. We are not allowed to do mock, hate and hurt.Islam teaches us that the race, tribe, ethnic group, and religion differences is not the basis for us to hate the neighbor.But if other people do the intimidation, hostile and fight,then we are allowed to defend.As the word of Allah in the Qur'an surah Al Mumtahanah verse 8 which means:

"Allah tidak melarang kamu untuk berbuat baik dan berlaku adil terhadap orang-orang yang tiada memerangimu karena agama dan tidak (pula) mengusir kamu dari negerimu. Sesunggubnya Allah menyukai orang-orang yang berlaku adil (Q.S. Al Mumtahanah; 60:8).”

\section{Understanding the community prejudice, stereotyping and conflict}

It is difficult to be eliminated prejudice and stereotyping on the surface of the Earth. Prejudice and stereotype is the Almighty Sunnah. However prejudice and stereotyping can be reduced in a variety ways: 
1. Humans believe they have a scripture that is considered as a guidingfor life. There a lot wisdom that can be taken as a guide to life as state on the Quran;

"Hai orang-orang yang beriman, jaubilah kebanyakan prasangka, sesunggubnya sebahagian prasangka itu adalah dosa. Dan janganlah kamu mencari keburukan orang dan janganlah sebahagian kamu menggunjing atas sebahagian yang lain.......'[ QS Al Hujuraat; 49:12].”Dan kebanyakan mereka hanyalah mengikuti persangkaan saja. Sesunggubnya persangkaan itu tidak dapat mengalabkan kebenaran sedikitpun. Sesunggubnya Allab Maha Mengetahui apa yang mereka perbuat "[ QS Yunus; 10:36].

2. We should deepen the understandingour knowledge because of short-sightedness on ourselves in everyday life-a will bring the prejudice and stereotyping..

3. Do not partially understanding the religious teaching. Humansmust comprehensively understand about the religious teachings. The stereotypical views begin from lack of religious thought. The impact of it involve the scepticism to the other cummunity.

4. Subtract the exclusive thinking. Exclusivethinking can lead us to become selfish, unwilling to accept someone else's excess.It will be suspicious, prejudiced, and always makes negative issues which is based on hatred of others who do not agree with their community.

5. Dialogue between religions, cultures, and diverse community. If communication between the community we can wake up good, it will be creating a real understanding.It will increase the tolerance among communities.

6. Public awareness of the meaning of the importance of living together.Awareness acknowledges error. Acknowledge someone better than us and the 
realization that we are social beings. We are not a bunch of hypocrite who trying to prejudice.

Education is an adult human conscious effort to educate future generations. The generations who have a basic knowledge to reduce prejudices and stereotypes. Builds relevant concepts and supporting the existence and functioning of common life, among others: democracy, justice and law, cultural values and ethos, togetherness in equal differences, ethnicity, ethnic culture, religious beliefs, cultural expressions, private and public domains, human rights, cultural rights of the community and so forth.

The essence that needs to be built in the education system to reduce prejudices and stereotypes is to build awareness is multicultural. It is changing the way of view through teaching and learning by changing the essential, prejudiced and discriminatory monocultural perspective to a multiculturalist perspective that have diversity and difference, tolerant and open attitude values. It is not only such a paradigm shift demands an unlimited transformation to a mere cognitive dimension, but must also reach up to the dimensions of the student's affective and psychomotor.

Prejudice and stereotypes developing in the negative direction will bring society towards conflict. There are three factors in the conflict that is the factor of interest, power, right which is the source of conflict between two parties(Alo Liliweri, 2005, pp. 309-310). The picture of the relationship between the three factors as the object of the conflict can be seen in the figure 3,4 , and 5 .

Interest

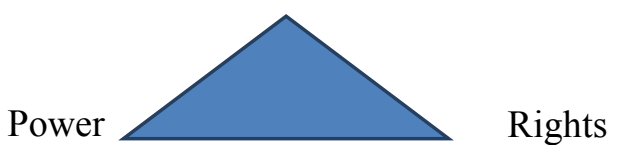

Figure 3. Three factors that drive conflict 


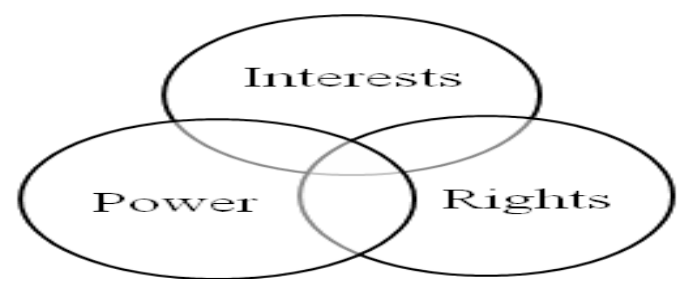

Figure4. Docking between the three factors that drive conflict

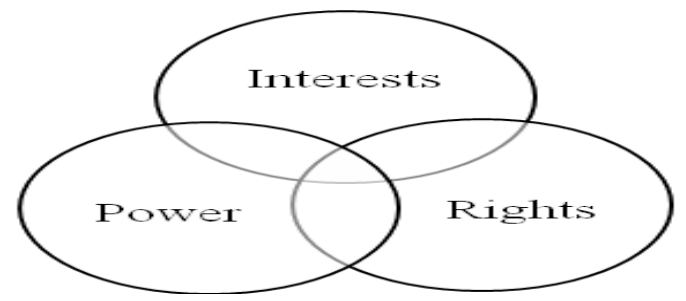

Figure 5. Docking between between the three factors in the plan conflict resolution

\section{Religion Inclusiveness}

Indonesia recognized as a sovereign state since declaring the independence on August 17, 1945. Islam is the big population in Indonesia. The Indonesian Islamic community is strongly influenced by the discourse of two different types of religious understanding. The first typology, called "Abangan Islam" which tends to understand Islam is limited to personal beliefs, sometimes even embracing Islam because of the lineage. Ironically most of them study in schools that embrace Western education system without balanced with education that leads to a comprehensive understanding of Islam that ultimately affects the pattern of Islamic thought. The second typology, often termed "Islamic Santri". This community still maintains a strong Islamic tradition in their daily life.They study in traditional boarding schools that have not adopted modern educational system. This two typologies often claim themselves as the most correct parties, and consider themselves most entitled to carry change. The 
first group accused the second group of being an exclusive Islamic group. While the second group claims the first group has been tarnished by the idea that came from the West and is far from the Islamic values (Firdaus M. Yunus, 2011, p. 223). The form of our concerns related to the Islamization in Indonesia conducesthe inclusive Islam.

The long debate about Islamic thinking in Indonesia is related to inclusive Islam, after the people are exposed to the thinking stage of "Rational Islam", then "Islamic Civilization" and "Transformative Islam". The religious presence of "inclusive Islam" is a form of resistance to an exclusively closed and religious understanding which is confined to dogmas and mythology. Though the reality of Islamic society is in modern life that demands a truth proved by scientific reasoning empirically, logically and systematically. Deconstruction of understanding of the "dogma" that is done does not mean negate, as state byHidayat Komarudin (1999, pp. 91-100)but toward conceptual reconstruction and spiritual ascenta servant leads to the absolute reality. Islamic teachings are the source to promote a peaceful, tolerant atmosphere of religious life over other religions, in pluralistic and multicultural pluralistic societies.

\section{Peran Organisasi Masyarakat Islam dalam Menjaga Keragaman dan Keberagamaan yang Inklusif di Indonesia}

The definition of social organization is regulated in Law Number 17 Year 2013 on Social Organization in article 1, paragraph 1. Organization is an organization founded and formed by the community voluntarily based on the similarity of aspirations, wills, needs, interests, activities, and objectives to participate in development in order to achieve the objectives of the Unitary State of the Republic of Indonesia based on Pancasila.(Menteri Hukum dan Hak Asasi Manusia 
RI, 2013).The freedom of association principle specified inconstitutionclause 28 year 1945. Constitutional guarantees as contained in the 1945 constitution second amendment in article 28 E verse (3)(BPN, 2002, pp. 8-9).

Ormas dimasa reformasi mempunyai 3 peranan penting: 1). Sebagai Salah satu pilar dari pembangunan Bangsa. 2). Sebagai salah satu badan atau organisasi yang mempunyai hak mengontrol kebijakan pemerintah. 3). Sebagai kelompok penekan,jika pemerintah mulai melenceng dari azas dan aturan- aturan yang berlaku.

Mass organizations in the reformation era have three important roles: 1). As one of the pillars of nation building. 2). As one body or organization that has the right to control government policy. 3). As a pressure group, if the government begins to deviate from the principles and rules that apply.

Islam is a religion that teaches its people to be actively involved in all aspects of life, not only in theological, and ritual process. Muslims must be the leading people to help mankind. Islamic teachs people to be widely active and involve in social life. As a form of the implementation of these teachings, emerged institutionalized social activities as the beginning of the emergence of community organizations based on Islam in Indonesia. During this time Islamic mass organizations are considered capable of protecting Muslims because it was established with the aim to meet the needs of its members in the field of religious. It requires at least three approaches in order to explore the religiousness in a social context, namely social approach, religious approach, and psychological approach. The most dominant of the three is the combination of social and religious approaches embodied in the discipline of religious sociology(Novianti, 2008, p. 2). 
A diverse approach for understanding the reality of the existing Islamic organizations pluralism in Indonesian society will bring a dynamic cultural diversity all the time. The culture dynamism is strongly influenced by economic systems, technologies, knowledge, religion, social organization, language, and art. Therefore we need to respond wisely in the process of existing Islamic mass organizations management. Existing Islamic mass organizations management are based on Local Wisdom. This can take the form of: a). ideas, values, norms, regulations, b). behavior patterns, complex activities, c). Artefacts, cultures, materials and cultural products (Koentjaraningrat, 1990, p. 5).

The community organizations and Islamic organizations understanding in general based on local wisdom is expected to be an effective, efficient and productive tool in maintaining the tolerance of religious communities in Indonesia. Where tolerance can be interpreted as giving freedom to human in order to run his belief or manage his life, determine his fate respectively, as long as in regulating and determining his attitude is not violating and not contrary to the principle of creating order and peace in society (Hasyim Umar, 1979, p. 66).

The government has a strategic role to manage all community organizations in a communicative, transparent, accountable and controlled manner. It is expected that every organization will make a positive contribution in national development processes. The existence of Islamic mass organizations is a place for religious people to perform religious movements, both internally and externally. This is to adapt to society in general on social, cultural, economic, political, theological and ritual aspects. An Islamic organization can be seen from the perspective of structure, function and group changes. Finally communication with the 
mass organizations can be done to control the condition of people who experience very rapid changes in disruption era.

The ideological, cultural, social, economic and political aspects of people's lifestyles change very quickly. Everything that is done in this disturbing era will not always run linearly. There will be many surprises, the irregularities that occur to achieve a better-regarded goal. Consequently Islamic social organizations must be able to adapt to the digitalization of web-based organization systems and also face to face that is maximally utilized to communicate, plan, direct, mobilize, mobilize, organize, control and evaluate.

\section{Research Methods}

This research used Secondary Data analysis researchwith qualitative approach. As Clifford Geertz defines as understanding of understanding, which is to understand social phenomena with the understanding of the world's own attituge. The emic approach is in line with the assumption of qualitative research that humans are active beings whose behavior can be understood through their cultural system(Bungin Burhan, 2003, pp. 66-70). Data collection techniques with secondary data through the internet media to search for as many all research subjects using search engine facilities. For example through Google, MSN, Yahoo, Gmail, and Wikipedia so that it gets scientific journals, newspapers, news portals, research results from research institutions, and documents.(Wallace Foundation, 2014). Next step for analyzing the data (1). Indentifying sources of information, (2).Gathering the existing data, (3). Normalizing the data needed, (4). Analyzing data. 


\section{B. Result}

\section{Islamic Mass Organization in Indonesia}

\section{a. Perkembangan Ormas Islam di Indonesia}

Indonesia is a country that has religious variety and diversity in their community. Such pluralism leads to diversity in association and assembly in the form of mass organizations. The existence of mass organizations would be a necessity that can not be eliminated. The existence of mass organizations managed by communicative, controlled, transparent, and accountable, it will be able to become a buffer in the existing national development processes. The formation of non governmental organization is needed by the community. It can be seen from the development of organizations which is always increasing in every year. Based on data from the Ministry of Home Affairs in June 2017 the number of mass organizations are about 344,039 . There are 370 mass organizations not incorporated but in the form of registered certificate. The existing Islamic community organizations in Indonesia at this time amounted to 72 as in table 1.

Table 1. The Islamic mass Organization in Indonesia

\begin{tabular}{|c|l|c|l|}
\hline No & \multicolumn{1}{|c|}{ Name } & No & \multicolumn{1}{|c|}{ Name } \\
\hline \hline 1 & Al Isrsyad Al Islamiyah & 37 & Wahdah Islamiyah \\
\hline 2 & Al Ittihadiyah & 38 & Majelis Az Zikra \\
\hline 3 & Al Washliyah & 39 & Majelis Dakwah Islamiyah \\
\hline 4 & $\begin{array}{l}\text { Dewan Dakwah Islamiyah } \\
\text { Indonesia (DDII) }\end{array}$ & 40 & $\begin{array}{l}\text { Majelis Ulama } \\
\text { Indonesia (MUI) }\end{array}$ \\
\hline 5 & $\begin{array}{l}\text { Dewan Masjid Indonesia } \\
\text { (DMI) }\end{array}$ & 41 & $\begin{array}{l}\text { Majelis Tafsir Al- } \\
\text { Quran (MTA) }\end{array}$ \\
\hline 6 & Forum Umat Islam (FUI) & 42 & Mathla'ul Anwar \\
\hline 7 & Front Pembela Islam (FPI) & 43 & Muhammadiyah \\
\hline 8 & $\begin{array}{l}\text { Forum Dakwah Islam } \\
\text { Indonesia (FDII) }\end{array}$ & 44 & Nahdlatul Ulama (NU) \\
\hline 9 & $\begin{array}{l}\text { Harakah Sunniyah Untuk } \\
\text { Masyarakat Islami (Hasmi) }\end{array}$ & 45 & Nahdlatul Wathan (NW) \\
\hline
\end{tabular}


The Islamic Mass Organization Contribution in Protecting...

\begin{tabular}{|c|c|c|c|}
\hline 10 & Hidayatullah & 46 & Pemuda Muslimin Indonesia \\
\hline 11 & Hizbut Tahrir Indonesia (HTI) & 47 & Persatuan Islam (Persis) \\
\hline 12 & $\begin{array}{l}\text { Ikatan Cendikiawan Muslim } \\
\text { Indonesia (ICMI) }\end{array}$ & 48 & $\begin{array}{l}\text { Persatuan Islam Tionghoa } \\
\text { Indonesia (PITI) }\end{array}$ \\
\hline 13 & Ikatan Da'i Indonesia (Ikadi) & 49 & Persatuan Ummat Islam (PUI) \\
\hline 14 & $\begin{array}{l}\text { Lembaga Dakwah } \\
\text { Kemuliaan Islam (LDKI) }\end{array}$ & 50 & $\begin{array}{l}\text { Persatuan Tarbiyah } \\
\text { Islamivah (Perti) }\end{array}$ \\
\hline 15 & $\begin{array}{l}\text { Lembaga Dakwah Islam } \\
\text { Indonesia (LDII) }\end{array}$ & 51 & $\begin{array}{l}\text { Syarikat Islam } \\
\text { Indonesia (SII) }\end{array}$ \\
\hline 16 & $\begin{array}{l}\text { Majelis Intelektual dan Ulama } \\
\text { Muda Indonesia (MIUMI) }\end{array}$ & 52 & $\mathrm{BP} \varepsilon 1$ \\
\hline 17 & Al Bayyinat & 53 & 'Aisyiyah \\
\hline 18 & Al Hawariyun & 54 & Fatayat NU \\
\hline 19 & $\begin{array}{l}\text { Badan Kerjasama Pondok } \\
\text { Pesantren Indonesia (BKsPPI) }\end{array}$ & 55 & Front Pemuda Islam (FPIS) \\
\hline 20 & $\begin{array}{l}\text { Badan Komunikasi Pemuda } \\
\text { Remaja Masjid Indonesia } \\
\text { (BKPRMI) }\end{array}$ & 56 & $\begin{array}{l}\text { Forum Komunikasi Aktivis } \\
\text { Masjid (FKAM) }\end{array}$ \\
\hline 21 & $\begin{array}{l}\text { Badan Kordinasi Masjid } \\
\text { (BAKORMAS) }\end{array}$ & 57 & Forum Pemuda Sunny \\
\hline 22 & $\begin{array}{l}\text { Gerakan Nasional Patriat } \\
\text { Islam (GNPI) }\end{array}$ & 58 & $\begin{array}{l}\text { Ikatan Da'i Muda Indonesia } \\
\text { (IDMI) }\end{array}$ \\
\hline 23 & $\begin{array}{l}\text { Gerakan Pemuda Ansor (GP } \\
\text { Ansor) }\end{array}$ & 59 & $\begin{array}{l}\text { Ikatan Mahasiswa } \\
\text { Muhammadiyah (IMM) }\end{array}$ \\
\hline 24 & $\begin{array}{l}\begin{array}{l}\text { Himpunan Mahasiswa Islam } \\
(\mathrm{HMI})\end{array} \\
\end{array}$ & 60 & $\begin{array}{l}\text { Ikatan Pelajar Nahdlatul } \\
\text { Ulama (IPNU) } \\
\end{array}$ \\
\hline 25 & Hizbul Wathan & 61 & $\begin{array}{l}\text { Ikatan Pelajar } \\
\text { Muhammadiyah (IPM) }\end{array}$ \\
\hline 26 & $\begin{array}{l}\text { Jam'iyyah Ahli Thariqah Al- } \\
\text { Mu’tabarah An-Nahdliyah }\end{array}$ & 62 & $\begin{array}{l}\text { Ikatan Sarjana Nahdlalul } \\
\text { Ulama disingkat ISNU }\end{array}$ \\
\hline 27 & $\begin{array}{l}\text { Keluarga Alumni Masjid } \\
\text { Kampus Indonesia } \\
\text { (KAMPUSINA) }\end{array}$ & 63 & Muslimat Nahdlatul Ulama \\
\hline 28 & Laskar Arif Rahman Hakiem & 64 & Muballighah Bulan Bintang \\
\hline 29 & Laskar Pembela Islam (LPI) & 65 & Muslimah Hidayatullah \\
\hline 30 & Majelis Dakwah Islamiyah & 66 & Nasyiatul Aisyiyah \\
\hline 31 & $\begin{array}{l}\text { Majelis Dzikir dan Dakwah } \\
\text { Islam (MADDIA) }\end{array}$ & 67 & Pelajar Islam Indonesia (PII) \\
\hline 32 & $\begin{array}{l}\text { Persyarikatan Da'wah Al } \\
\text { Haromain }\end{array}$ & 68 & Pemuda Muhammadiyah \\
\hline 33 & Rabithah Alawiyah & 69 & Pemuda Muslimin Indonesia \\
\hline
\end{tabular}




\begin{tabular}{|c|l|c|l|}
\hline 34 & Sarekat Islam & 70 & $\begin{array}{l}\text { Pergerakan Mahasiswa Islam } \\
\text { Indonesia (PMII) }\end{array}$ \\
\hline 35 & $\begin{array}{l}\text { Serikat Buruh Muslimin } \\
\text { Indonesia (SARBUMUSI) }\end{array}$ & 71 & $\begin{array}{l}\text { Persatuan Guru Nahdlatul } \\
\text { Ulama (PERGUNU) }\end{array}$ \\
\hline 36 & Syabab Hidayatullah & 72 & Wanita Syarikat Islam \\
\hline
\end{tabular}

In the late nineteenth and early twentieth centuries Islamic organizations in Indonesia have been transformed as a result of changes in the Islamic world. The background of the founding of these organizations is largely based on Muslims' desire to escape from colonialism. The organization has a religious, political or social ideology. Starting from the renewal movement that emerged in the Middle East region. The Dutch government has sought to stem the effects of these movements, but Muslim leaders in Indonesia at the time still received brochures and magazines containing the thought of Islamic renewal in the Middle East.

Based on the inspiration of Islamic reform thinking figures, the emergence of Islamic community organizations that have been formed by the figures in Indonesia. Some Islamic organizations at that time were:

1) Nahdlatul Ulama' (NU)

$\mathrm{Nu}$ is a religious social Islamic organization (Jam'iyah diniyah Islam founded on January 31, 1926 or 16 Rajab $1334 \mathrm{H}$, with Aswaja or Ahlu Sunnah wal-jamaah.NU was founded by Hasyim Ash'ari along with the scholars and businessmen from East Java.

2) Muhammadiyah

Muhammadiyah is an Islamic reform organization in Indonesia, founded by K.H. Ahmad Dahlan. This organization is actually a long chain of various reforms of the pre-existing Islamic movement. Such figures as Rashid Rida, Sayyid Jamaludin al-Afghani, Ibn Taymiyyah, Muhammad Abduh, Muhammad bin 
Abdul Wahab, Ibn al Qayyim al-Jawziyah and various other Muslim leaders.

3) Rabithah Alam Islami

Rabithah Alam Islami is an international Islamic organization established in May 1962 AD or Zulhijah 1381 Hijriyah. The United Nations (UN) categorizes non-governmental organizations and this orgaslation is a member of OIC observers (Organization of Islamic Conference) and UNESCO.

4) Himpunan Islam Indonesia

The Islamic Students Association (HMI) is an organization of students in Indonesia. This organization many print Muslim politicians who led the nation, such as H. Yusuf Kalla, Akbar Tanjung, Anas Urbaningrum and others.

5) Jama'ah Tabligh

Jama'ah Tabligh or JT is a familiar jama'ah islamiyah whose axis of preaching about the delivery (tabligh) the virtues of Islamic teachings. This Jama'ah will reach every class and layers of society that can be reached. Jama'ah Tabligh perform da'wah from mosque to mosque and door to door. This Jama'ah used to walk from one mosque to another and stay in it. Jama'ah Tabligh stay away from political problems because from their place of origin in India, Muslims are a minority.

6) Hizbut Tahrir (HT)

Hizb ut-Tahrir (HT) is an Islamic organization engaged in politics. Islamic ideology and political activity, that's Hizb ut-Tahrir. Despite the political movements, Hizb ut-Tahrir is very anti-democratic. Hizb ut-Tahrir always voiced the establishment of the Khilafah and enforced 
the shari'ah law in his life, the organization is moving in the midst of Muslims.

7) Al-Irsyad Al-Islamiyyah

Al-Irsyad, Muhammadiyah and Persis (Islamic unity) are the three powerful Islamic reformers in Indonesia. In the early twentieth century there have been a number of elite Muslim figures who have a renewed spirit in the religious mindset.

8) Ikhwanul Muslimin

The Muslim Brotherhood is the largest Islamic movement in modern times. His call is to return to the Qur'an and AsSunnah and to invite the people to return to the application of the Islamic Shariah in real life. This movement is also one that is stemming the flow of secularization in the Islamic world. The Muslim Brotherhood in Indonesia formed a party now known as Partai Keadilan Sejahtera (PKS)(Aprianasara, 2018).

\section{b. The Islamic Mass Organization Popularity}

Many surveys have been conducted by the survey institute with slight differences of views on the popularity of Islamic mass organizations in the community. Among them are said that there are five Islamic mass organizations are popular in the community of NU, Muhammadiyah, FPI, Hidayatullah and Persatuan Islam (Persis). Furthermore, from 72 Islamic organizations based on Alvara Research Center and Mata Air Foundation survey, there are five Islamic community organizations that are best known to students, namely Nahdlatul Ulama, Muhammadiyah, Front Pembela Islam (FPI), Lembaga Dakwah Islam Indonesia, and Hizbut Tahrir Indonesia. When viewed from the Popularity NU and Muhammadiyah are two Islamic organizations are best known to students. Among adolescents and students, NU, 
Muhammadiyah, and FPI mass organizations are known in the figure of 60 to $100 \%$. While LDII and HTI are better known among the students than the students around $48.5 \%$ and $37.2 \%$ of students know LDII and HTI. While the number of students is $41.4 \%$ and $21.7 \%$.

Despite knowing a number of mass organizations, the majority of Alvara respondents said not close to any organization. Some respondents stated that it is close to NU (34.7\% students and 45.4\% students) and Muhammadiyah (11.6\% students and $13.6 \%$ students). There are also students who claim close to FPI, HTI, MTA (Majelis Tafsir Al Qur'an), and FUI (Forum Umat Islam). When asked about membership to one of the mass organizations, NU and Muhammadiyah have the most members among students and students. The result says there are 27.2 percent of students and 22.5 percent of students declare themselves as NU members. While 6.3 percent of students and 4.1 percent of students admitted Muhammadiyah members. The survey was conducted on 2,400 students and 1,800 students. The student respondents came from 25 favorite universities in Indonesia with certain majors. The departments are supplying the labor market in seven sectors, namely defense and security sectors, finance, energy and food, telecommunications and logistics, health, education, manufacturing and infrastructure. While the student respondents are drawn from five state high schools of excellence or favorites in every district and city in Java Island as well as some big cities outside Java Island. The survey was conducted from 1 September to 5 October 2017 with a margin of error of 2.35 percent for student surveys and 2 percent for student surveys(Budiarti Utami Putri, 2017).

Based on the survey results, it is agreed that there are at least three of the most popular Islamic organizations, 
namely Nahdlatul Ulama (NU), Muhammadiyah, and FPI (9\%). $\mathrm{NU}$ is an Islamic organization that is considered to uphold the values of tolerance.

\section{c. The Pros and Cons of Islamic Organization Revocation}

The government is obliged to discipline all existing organizations by establishing a set of rules in the form of mass organizations, government regulations and ministerial regulations. Of course, for organizations that have been proven to actually commit some violations in the regulation, the government is entitled to give warning, guidance to the revocation of the permit of the organization (dissolution of the organization) concerned.

The government has a desire to dissolve Islamic organizations that are considered radical to endanger the life of the nation and state is against the principles of Pancasila and the 1945 Constitution. At least there are six mass organizations indicated to be dissolved: (1). Hizbut Tahrir Indonesia (HTI), (2). Aliansi Nasional Anti Syiah (ANNAS), (3). Jamaah Ansarut Tauhid (JAT), (4). Majelis Mujahidin Indonesia (MMI), (5). Forum Umat Islam (FUI), (6). Front Pembela Islam (FPI).

The pros and cons have taken place in the dissolution process, after the government has made a firm decision to dissolve the Islamic organization Hizbut Tahrir Indonesia (HTI) which is considered radical and undermines Pancasila and the 1945 Constitution, based on Government Regulation in Lieu of Law (Perppu) Number 2 Year 2017 on the Organization. The dissolution of the government has received support from 14 members of Lembaga Persahabatan Ormas Islam (LPOI) they are Nahdlatul Ulama, Al-Irsyad Al-Islamiyah, Al Washliyah, Persatuan Umat Islam (PUI), Persatuan Islam (PERSIS), Persatuan Tarbiyah Islamiyah 
(PERTI), Mathla'ul Anwar, Yayasan Az Zikra, Al-Ittihadiyah, Ikatan Dai Indonesia (IKADI), Rabithah Alawiyah, Persatuan Islam Tionghoa Indonesia (PITI), Nahdlatul Wathan and Himpunan Bina Mualaf Indonesia (HBMI). The dissolution of HTI has been protested by filing a lawsuit that is still in the process of trial.

\section{Diversity and religiousness of the Indonesian people}

Indonesia is a country with abundant natural resources and human resources spread from Aceh to Papua with 17,504 islands and there are more than 250 or even 500 tribes as well as the growth of religious tolerance. The population to date amounts to 257,912,349 people (Mendagri, 2017). The large number of people followed by scattered throughout the territory of Indonesia, encouraging us to realize that the Indonesian is a pluralistic nation. Pluralism can be seen from diversity and religious community.

Keragaman masyarakat dan bangsa Indonesia dapat dilihat dari banyaknya keragaman sosial, budaya, politik, dan ekonomi, seperti dinyatakan dalam motto nasional «Bhinneka Tunggal Ika (Bhina = berbeda banyak; Tunggal = Satu). Oleh karena itu, keragaman tersebut tentu berpengaruh langsung terhadap pengelolaan pemerintah dalam proses-proses pembangunan nasional. Artinya, pendekatan pluralisme dan multikulturalisme dalam pembangunan nasional adalah suatu keharusan yang tak dapat diabaikan lagi.

The Indonesian society diversity can be seen from the multitude of social, cultural, political and economic diversity, as stated in the national motto «Bbinneka Tunggal Ika" (Bhina=different; Tunggal=one). Therefore, it certainly has a direct effect on the government management in the processes of national development. The pluralism and 
multiculturalism approach in national development can not be ignored anymore.

The diversity of Indonesia is actually taken for granted. It is not come from the immigrant who have different ethnic, racial or religious. At the first time the Indonesian people are plural as well as heterogeneous. The reality of Indonesian diversity is illustrated in two geographical and ethnographicdimensions (Kusumohamidjojo, 2000, p. 16). First, the geographical dimension as observed by Alfred Wallace and Weber is then confirmed in Geography as the Wallacea Line extending from the Sulu Sea in the north through the Makassar Strait to the Lombok Strait to the south.The Weber Line stretching from the western shore of Halmahera Island in the north through Seram Sea to the Timor Sea in the south. The Wallacea and Weber lines physically geographically distinguish the Sunda Dangkalan in the West (which includes the islands of Sumatra, Kalimantan, Java and Bali) from the Central Indonesian Dangkalan (which includes the islands of Sulawesi and parts of the islands of West Nusa Tenggara). From Dulalan Sahul to the east (which includes the islands of Halmahera, Aru and Papua). That difference is the result of the physiologicalgeographical development process left by the end of the Ice Age. Geographical differences that result in determining differences in the world of flora and fauna in each group of islands. The second dimension is an ethnographic dimension, which is aconsequences fusion from the physico-geographic dimension and the process of ancient nations migrating. Within the framework of the entomic dimension we can see the existence of ethnic differences in the population that inhabit the various islands of the archipelago is not less than 500 tribes. 
The diversity characteristics of of Indonesian society as Dikdik Baehaqi Arif (2013, p. 2) which is seen in geography and ethnography as a form of diversity and religiousness of the Indonesian nation is characterized by our desire to unite in the Unitary State of the Republic of Indonesia. In order for us to unite, we must understand the diversity of the Indonesian nation in which it can be seen both vertically and horizontally. Vertically, the diversity of our nation can be seen from different levels of education, economy, settlement, occupation, and socio-cultural level. While horizontally, the diversity of the Indonesian nation can be seen from different religions, ethnic, regional languages, geographical, clothing, food, and culture.

The Indonesian plurality and heterogeneity, there is a tremendous power (as social and cultural capital) to unite in achieving the goal for a just, prosperous and dignified national development for every citizen. Plurality and heterogeneity in addition to giving positive side effects as described above, is also stored a negative impact, because because of the diversity factor that is often lead to conflict between groups of people that result in security distability, threats ideology, socio-economic, and social disharmony (social disharmony) as in table 1 below.

Tabel1.Positive and Negative Impact of Indonesian Nation's Diversity

\begin{tabular}{|c|c|c|}
\hline $\begin{array}{c}\text { The Elements of } \\
\text { Diversity }\end{array}$ & Positive side & Negative side \\
\hline $\begin{array}{ll}\text { - } & \text { Ethnicity } \\
\text { - } & \text { Race } \\
\text { - } & \text { Tribes } \\
\text { - } & \text { Culture } \\
\text { - } & \text { Religion } \\
\text { - } & \text { Beliefs } \\
\text { - } & \text { Panguage } \\
\text { - } & \text { Econitics } \\
\text { - } & \text { and so forth }\end{array}$ & $\begin{array}{l}\text { - The community } \\
\text { binding to unite against } \\
\text { the invaders embodies } \\
\text { the goals of national } \\
\text { development. } \\
\text { - The nature of diversity } \\
\text { strengthens the united } \\
\text { desire to achieve shared } \\
\text { ideals in national } \\
\text { development programs }\end{array}$ & $\begin{array}{l}\text { - Promotes conflict } \\
\text { between groups of } \\
\text { people. } \\
\text { - Distribution of } \\
\text { security } \\
\text { - Social-economic, } \\
\text { - The threat of Ideology } \\
\text { - Social disharmony } \\
\text { (social disharmony) } \\
\text { - Injustice to society } \\
\text { - Legal Uncertainty }\end{array}$ \\
\hline
\end{tabular}


While the religious for the people of Indonesia have obtained the guarantee as regulated in the 1945 Constitution in Chapter XI on Religion article 29 paragraph 1 and 2 which reads: (1) State based on Belief in the Almighty. (2) The State guarantees the freedom of every citizen to embrace his or her own religion and to worship according to his religion and belief (BPN, 2002, p. 19). Religions recognized by the Government, according to the Ministry of Religion there are only six are Islam, Christianity, Protestantism, Hinduism, Buddhism, and Konghuchu. Although there are citizens who embrace a belief stream other than six, the ministry of religion will not discriminate (Kementerian Agama, 2013).

The diverse reality of Indonesian society will positively impact the religious and ethical life of the community that will contribute to the national development process. On the contrary, negatively impact the conflict-ridden society if not properly managed by the different beliefs. Therefore we need to maintain the creation of harmony among religious people. Forum Kerukunan Umat Beragama (FKUB) which has been formed communicate among religious people to reduce prejudice, stereotypes and conflict.It to create tolerance values in an inclusive religious frame (open religious) both among and / or within religious communities that will eventually create a religious, ethical society , safe, fair, and prosperous.

\section{The Role of Islamic Society Organizations in Maintaining Diversity and Inclusive Culture in Indonesia}

Pluralism is Allah SWT mercies and also at the same time mafsadah if we are not able to manage well based on the potentials diversity. The birth of the discourse of Inclusive Islam is the antithesis of religious understanding, there is a tendency to think black and white; the assumption that we are the righteous, those who are wrong, we are the most 
righteous and they are perverted. The rigid understanding of Islamic teachings, will cause religious problems when faced in a plural and multicultural society, there will even be prolonged conflict. As the current incidence of religious and inter-religious degradation of religious tolerance has been widespread in the form of "harassment" of religious teachings as a result of the religion way of knowing which always prioritizes the claim truth interpretation by giving stigma to another interpretation which makes social distance as well as the practice of domination and the desire of power often coloring religious relationships. If it proclaimed, would be a source of conflict in the name of religion. Therefore, on behalf of a religious believer, it is not allowed to harass, prejudice and terrorize one's religious activity. It noted that conflicts which sourced from religion never be completely resolved peacefully, even escalation of violence or conflict is splayon the theological legitimation followed over the violence that occurs is considered something sacred or holy. Yet the presence of religion expands the salvation of man's mission in this world to the future. Religion is revealed to humans as a form of rahmatan lil 'alamin.

There are two important things related to the role and function of the formation of Islamic organizations (1) it formed with the aim of keeping the unity and unity of the nation is not acting anarchist and violating the law, (2) it formed as a means of channeling the aspirations of the community. Society must be selective in choosing existing Islamic organizations by always checking the vision and mission and the foundation principle. It is expected that the public can conduct the aspirations of the Islamic organization, as a contribution to the national development process.

The role of Islamic organizations in actively participating to contribute positively in maintaining the 
diversity and religiousness. The inclusive of Indonesia can be categorized into two things: (1) The role of Islamic organizations in maintaining kebhenikaan in Indonesia, (2) The role of Islamic organizations in the development of Islamic Education in Indonesia.

\section{The role of Islamic organizations in maintaining kebhenikaan in Indonesia}

Islam is the religion of the lil 'alamin rahmatan that upholds the value of compassion to all beings. Every human being who is born to be the leader of the earth (khalifah fil ardhi). One of the tasks of a leader is to create harmony on earth. Compassion aims to create a harmonious life among fellow human beings including in Indonesia. Although in reality, today many negative issues that have cornered Islam. Islam is considered a religion that is identical with intolerance, terrorism and conflict. Yet Islam has historically led to the nation of Indonesia to the gate of independence with the heroes who mostly fell in the struggle of the united state of the republic of Indonesia (NKRI). Islam is the foremost guard in maintaining the unity of the Indonesian nation. Based on the historical reality of the contribution of Muslims to the Indonesian nation, it is considered necessary for Muslims to involve themselves in Islamic organizations that aims to build the progress of Islam in all aspects of life, especially Muslims in Indonesia.

The real contribution of Muslims can be given to the Indonesian nation, if able to involve ourselves on three major forces namely religious, economic and political power. In the third Islamic perspective it is a power that can not be separated from one another. Islam does not separate religion, politics and economy. All three are the forces that we must unite, if we unite it will lead us in the progress of 
Muslims from now to the future. Muslims become superior and winners in all aspects of life.

Muslims have an important position in liberating the state of Indonesia. The two major organizations for Muslims namely Muhammadiyah and Nahdlatul Ulama that emerged as a result of colonialism, backwardness, stupidity, poverty and consequence of tradition, have awakened our consciousness to struggle in the framework of increasing dignity for the Indonesian, formal, informal, and non-formal education and organizations. Muhammadiyah which was established in 8 Dzulhijjah $1330 \mathrm{H} / 18$ november $1912 \mathrm{M}$ in the village of kauman Yogyakarta led by K. H Ahmad Dahlan. Persyarikatan muhammadiyah was established to support the efforts of $\mathrm{KH}$ Ahmad Dahlan to purify the teachings of Islam which, according to his presumption, much influenced the mystical things that resulted in the stagnation of thinking and acting in responding to all aspects of life. Nahdlotul ulama (NU) which was also established since 31 January 1926 in the city of Surabaya led by K.H Hasyim Asy'ari and engaged in education, social and economic. Some of the factors behind the establishment of NU, among them is the development and renewal of Islamic thought that requires the prohibition of all forms of amalishment of the sunny.

The existence of Islamic organization serves as a medium of da'wah for Muslims who are needed, the goal that Muslims have a reference, ie from the scholars who exist in the organization, and guided by the Qur'an and Al Hadis, in order not to oscillate with issues of terrorism, human rights abuses, intolerance and so on. Muslims should have legal and formal Islamic organizations with a clear role in the national development process. Where in essence in the process of national development a nation can be achieved through a process that begins by building public awareness 
of a common goal and goal. The common goal of achieving common goals and interests can be realized if a group of people form a public organization.

Whereas the idealities of Islamic organizations would be an important element to strengthen the rule of law supremacy and maintain the unity of unity and unity of the nation. Islamic organizations become strategic partners in maintaining the diversity and diversity that need attention. The involvement of Islamic organizations both individually and in groups becomes an important factor in building the conduciveness of national life.

Nahdlotul Ulama and Muhammadiyah is the largest organization in Indonesia, Islamic organizations are expected to keep the unity of the nation and state in Indonesia, and also the government should be a pioneer and a driver of society in realizing a harmonious social life. In harmony with Law No. 7 of 2012 Article 9 stating that, "The Government and the Regional Government shall reduce the potential for social conflict in the community"(Menteri Hukum dan Hak Asasi Manusia RI, 2012). Where every mass organizations should be based on Pancasila and the 1945 Constitution. As mandated in Article 21 paragraph (b) about the obligations of the Organization that is "Menjaga persatuan dan kesatuan bangsa serta keutuhan Negara Kesatuan Republik Indonesia". The existence of mass organization that are opposite with Pancasila and the Constitution should be dealt with firmly. This is feared will potentially lead to greater horizontal conflicts.

\section{The role of Islamic organizations in the Indonesia Islamic Education Development}

The development of Islamic Organizations in Indonesia has reached 72 organization. The role of Islamic organizations is related to the development of education in 
Indonesia can be categorized into two namely: (1) The role of Islamic organizations that are national and even international and (2) the role of local-scale Islamic organizations.

a. The National and International of Islamic organizations role

Islamic organizations that play national and international level have their own branches in the provincial capital as well as regency / municipality capitals, such as: Nahdlatul Ulama (NU), Muhammadiyah, Sarikat Islam (SI), Persatuan Tarbiyah Islamiyah (PERTI), Majelis Ulama Indonesia (MUI), Majelis Da'wah Islamiyah (MDI), Dewan Mesjid Indonesia (DMI), Ikatan Cendekiawan Muslim se Indonesia (ICMI), Himpunan Mahasiswa Islam (HMI), Persatuan Mahasiswa Islam Indonesia (PMII), Aisyiah, Muslimat NU and so forth.

a. The role of local-scale Islamic organizations

Organisasi keagamaan Islam yang bersifat lokal pada umumnya bergerak di bidang da'wah dan pendidikan seperti: Majelis Ta'lim, Yayasan Pendidikan Islam, Yayasan Yatim Piatu, Lembaga-Lembaga Da'wah Lokal, dan sebagainya. Dalam pembinaan keberagamaan remaja organisasi kemasyarakatan (ormas) Islam memainkan peran sebagai pendidikyang lebih cenderung kepada penanaman nilai-nilai (ajaran) agama yang bersifat normatif dan yang bersifat ubudiyah, terutama dalam pembinaan pelaksanaan ibadah (shalat dan puasa). Sementara itu, pembinaan keberagamaan yang menyangkut masalah-masalah sosial (penyelesaian konflik, pengembangan diri remaja yang meliputi pendidikan yang bersifat kewiraswataan dan masalah narkoba serta AIDS) masih perlu ditingkatkan. 
Local Islamic organizations are generally engaged in da'wah and education such as: Majelis Ta'lim, Islamic Education Foundation, Orphan Foundation, Local Da'wah Institutions, and so forth. In the religious formation of adolescents, Islamic community organizations plays the role of educators who are more inclined to the religion values, especially in the development of the implementation of worship (prayer and fasting). Meanwhile, religious development involving social issues (conflict resolution, adolescent self-development including education of entrepreneurship, drug and AIDS issues) still needs to be improved.

\section{The Community Organization Obstacles and it Solutions.}

Community organizations formed by the public should participate in the development of the state in order to achieve the objectives of the Unitary State of the Republic of Indonesia based on Pancasila and the Constitution of the State of the Republic of Indonesia Year 1945 (Menteri Hukum dan Hak Asasi Manusia Republik Indonesia, 2017 , p. 2). Internal obstacles faced by mass organizations today are at least five issues: (1) the number of interests within the organization itself, (2) insufficient financial, (3) insufficient human resources, (4) Differences of opinion about the mass organization target, 5) Leadership dualism, (6) The lack of access to information and communication technology. There are several solutions that can be offered to overcome the barriers: (1) Early detection of many interests in the body mass organizations, either individually or class, especially selectivity in receiving binding fund sponsors, (2) Make organization financial plan (3) Focueses on human resources training in order to increase their competitiveness, (4) minimizing the existing differences with more seeking 
equality in determining the direction of the struggle of a mass organization, (5) Avoiding dualism of leadership by prioritizing deliberation and consensus in all forms of decisions, (6) Providing adequate stock for members in access to creative and innovative information technology.

The external problem faced by the organizationare; the media manipulation, difficulty toaccessthe data, the unavailability of thedataprovision by the government, as well as creating opponents who jumped directly to pit the fighters of these people. Therefore, Islamic organizations must be open and accommodative to all issues that exist with concrete steps in solving the problem of life of society and nation.In general there are several forms of concrete steps that have been taken by the mass organizations are: 1 ). Demonstration, 2). Dialogue with the government, 3). Making the government a partner, 4). Poll with the government, 5). Criticize through mass media, 6). Participating the government work program, 7). Following plenary sessions in DPR / DPRD to find out what policy will be made, 8). Public Coffe with the government, 9). Wrote to the government, 10). Doing theater, drama, and reflection in public places, 11). Free Opinion Stage, 12). Publicize da'wah activities in cyber social.

\section{Conclusion}

Diversity and religiousness of Indonesia need to be guarded. Diversity always has the potential for conflict that must be anticipated in social interaction and dynamics, especially if the value of Bhinneka Tunggal Ika begins to erode, so mutual respect and mutual trust are reduced. Religious awakening is expected to occur in the internal tolerance and between religious communities, to create a religious life. The role and function of Islamic organizations (1) mass organizations formed with the aim of maintaining 
the unity and unity of the nation and, (2) Formed as a means of channeling the aspirations of the community. Islamic organizations must partner with the government in controlling various policies. As a channel for the aspirations of the people, Islamic organizations are more sensitive to various problems faced by society and nation. The organization are also suggested to be neutral. Each organization has to rely on four things: (1). Pancasila, (2) Bhineka Tunggal Ika, (3) UUD1945, and (4) NKRI within the framework of ensuring the integrity of the Indonesia. 


\section{REFERENCE}

Alo Liliweri. (2005). Prasangka dan Konflik : Komunikasi Lintas Budaya Masyarakat Multikultur. Yogyakarta: PT. LKIS Pelangi Aksara.

Aprianasara. (2018). Daftar Organisasi Islam yang Berpengaruh di Indonesia. Retrieved from https:// pasberita.com/organisasi-islam-di-indonesia/

BPN. (2002). Undang-Undang Dasar Republik Indonesia 1945. Retrieved from http://www.bpn.go.id/ PUBLIKASI/Peraturan-Perundangan/UndangUndang/undang-undang-dasar-1945-931

Budiarti Utami Putri. (2017). Lima Ormas Islam yang Paling dikenal Pelajar dan Mahasiswa. Retrieved from https:/ / nasional.tempo.co/read/1029490/lima-ormas-islamyang-paling-dikenal-pelajar-dan-mahasiswa

Bungin Burhan. (2003). Analisis data Penelitian Kualitatif,

Pemahaman Filosofis dan Metodologis ke Arah Model Penguasaan Model Aplikasi. Jakarta: Grafindo.

Capuzzi, D. \& Gross, D. R. (1997). Introduction to The Counseling Profession. Boston: Allyn and Bacon.

Depag. RI. (1990). Al-Qur'an dan Terjemahnya. Jakarta : Restu Bumi.

Dikdik Baehaqi Arif, M. P. (2013). Membingkai Keberagaman Indonesia: Perspektif Pendidikan Kewarganegaraan Program Kurikuler. In Penguatan Kompetensi Calon Praktikan PPL Program Studi PPKn (pp. 1-23). Yogyakarta: UAD Yogyakarta.

Dokhi Muhammad, D. (2016). Analisis Kearifan Lokal Ditinjau Dari Keragaman Budaya. Jakarta: Pusat Data dan Statistik Pendidikan dan Kebudayaan (PDSPK) Kementerian 
Pendidikan dan Kebudayaan Republik Indonesia Kemdikbud RI.

Firdaus M. Yunus. (2011). Menafsir Ulang Keberagamaan Umat Beragama. Jurnal Substantia, 13(2), 220-230.

Hasyim Umar. (1979). Toleransi dan Kemerdekaan Beragama dalam Islam Sebagai Dasar Menuju Dialog dan Kerukuan antar Agama. Surabaya: PT. Bina Ilmu.

Hidayat Komarudin. (1999). Melampui Nama-Nama, Islam dan Postmodernisme. Bandung: Wacana Mulia.

Kementerian Agama. (2013). http:/ /www.kemendagri.go.id/ news/2013/11/28/uu-hanya-akui-6-agama-kemenagpemeluk-agama- lain-tetap-bisa-jalankan-ibadahnya.

Kementerian Dalam Negeri. (2017). Data Organisasi Kemasyarakatan dan Lembaga Swadaya Masyarakat. Retrieved from www.kemendagri.go.id/ news/2017/08/30/ada-344039-ormas-di-Indonesia

Koentjaraningrat. (1990). Pengantar Ilmu Antropologi. Jakarta: Rineka Cipta.

Kusumohamidjojo, B. (2000). Kebhinnekaan Masyarakat Indonesia: Suatu Problematik Filsafat Kebudayaan. Jakarta: Grasindo.

Mendagri. (2017). DATA TERKINI, Jumlah Penduduk Indonesia Lebih dari 262 Juta Jiwa. Retrieved from http: / /jateng.tribunnews.com/2017/08/02/dataterkini-jumlah- penduduk-indonesia-lebih-dari-262juta-jiwa

Menteri Hukum dan Hak Asasi Manusia Republik Indonesia. (2017). Peraturan Pemerintah Pengganti Undang-Undang Republik Indonesia No. 2 Tabun 2017. Jakarta.

Menteri Hukum dan Hak Asasi Manusia RI. (2012). UndangUndang Republik Indonesia Nomor 7 Tahun 2012 
Tentang Penanganan Konflik Sosial. Retrieved from file:///D:/PENULISAN MARET 2018/jurnal ADDIN 2018 Islam/penanganan konflik UU-72012. pdf

Menteri Hukum dan Hak Asasi Manusia RI. (2013). UndangUndang Republik Indonesia Nomor 17 Tahun 2013 tentang Organisasi Kemasyarakatan. Retrieved from file:///D:/PENULISAN MARET 2018/jurnal ADDIN 2018 Islam/UU_2013_17.pdf

Menteri Sekretaris Negara RI. (1999). Undang-Undang Republik Indonesia Nomor 39 Tahun 1999 Tentang Hak Asasi Manusia. Retrieved from http://www. idionline.org/wp-content/uploads/2010/03/UUNo.-39-Th-1999-ttg-Hak-Asasi-Manusia.pdf

Mudzhar, M. A. (2005). Pengembangan Masyarakat Multikultural Indonesia danTantangan ke depan (Tinjauan dari aspek Keagamaan dalam Meretas Wawasan \& Praksis Kerukunan Umat Beragama di Indonesia). Jakarta: Badan Litbang dan Diklat Keagamaan Puslitbang Kehidupan Beragama Depag RI.

Muhammad Ridho. (2016). Keberagaman dan etos kerja masyarakat petani gubar desa giripurwo kecamatan purwosari kabupaten gunungkidul. Yogyakarta.

Novianti, I. (2008). Peran Ormas Islam dalam Membina Keberagamaan Remaja. Jurnal Dakwah Dan Komunikasi (Komunika), 2(2).

Nuh, M. (2014). Islam, Nilai Sosial, Sikap Keberagamaan Di Tengah Problem Kebangsaan. POLITIKA, 5(2).

Robertson Roland. (1993). Agama dalam Analisa Interpretasi dalam Sosiologi, terjemahan Abmad Fedyani Syaifudin. Jakarta: Rajawali Press. 
Rosita Endang Kusmaryani. (2011). Membangun karakter keberagaman pada anak-anak. In Seminar Nasional Pusat studi Pendidikan Anak Usia Dini. Yogyakarta: UNY.

Ruskhan Gaffar Abdul. (2007). Pemanfaatan Keberagaman Budaya Indonesia Dalam Pengajaran Bahasa Indonesia. Seminar Pengajaran Bahasa Indonesia Pertemuan Asosiasi Jepang- Indonesia Di Nanzan Gakuen Training Center, pp. 1-9.

Wallace Foundation. (2014). Workbook B: Conductiong Secondary Research. Retrieved from http://www. wallacefoundation.org/ 